BEEF FEEDLOTS IN SOUTHWESTERN KANSAS:

Local Change, Perceptions, And the Global Change ConteXt

Lisa MB Harrington

Max Lu

Harrington, L.M.B., and M. Lu. 2002. Beef feedlots in southwestern Kansas:

Local change, perceptions, and the global change context. Global Environmental Change 12(4):273-282. 


\title{
BEEF FEEDLOTS IN SOUTHWESTERN KANSAS: \\ Local Change, Perceptions, and the Global Change ConteXt
}

\begin{abstract}
.
Cattle feedlots, some of which have a capacity of tens of thousands of head, have become a major driving force in the local economy and changing landscape of southwestern Kansas. The feedlot industry also is one of the region's most important sources of carbonequivalent greenhouse gases. Changes to the beef industry are described, and the perceptions and attitudes of feedlot operators regarding climatic change issues and industrial change are analyzed based on a 1998 survey. The results indicate that a majority of feedlot respondents believe 'global warming' is mostly an unproven theory, and efforts to mitigate it are unwarranted.
\end{abstract}

Keywords agriculture, perceptions, greenhouse gas emissions, cattle

\section{Acknowledgments}

This research was supported by grants from the National Science Foundation (1920-KSU-NSF-8052), National Institutes for Global Environmental Change (LTW 62-12306519), and National Aeronautic and Space Administration (NAGW-4932) through the Association of American Geographers. We also would like to acknowledge related efforts by our co-investigators on these research projects, and especially survey assistance by SylviaLinda Kaktins.

Abbreviated title Kansas feedlots 
BEEF FEEDLOTS IN SOUTHWESTERN KANSAS: Local Change, Perceptions, AND the Global Change Context

\section{Introduction}

In the first six decades of the $20^{\text {th }}$ century, livestock raising was relatively diffuse and took place mostly in the settings of mixed farming and western ranches. However, in the last thirty to forty years, concentrated animal agriculture became the dominant model for beef production. In the process, cattle on feed (versus pasturage) relocated from the Corn Belt to a rather circumscribed area of the southern Great Plains to take advantage of the open space and favorable climatic conditions (relatively mild winter, low humidity, low rainfall). In addition, the region has an historic 'beef culture' from the days of large cattle ranches and cattle drives, with widespread acceptance of cattle feeding. Southwestern Kansas has emerged as one of the world's premiere beef-producing regions, with a concentration of very intensive animal feeding operations and meat packing facilities (Broadway 2000).

Commercial feedlots emerged during WWII and now dominate livestock production (Bussing and Self 1981, Saito and Yagasaki 1998). Cattle-feeding operations are particularly concentrated and intensive in Southwest Kansas and the neighboring Texas and Oklahoma panhandles (Figure 1). More than half of Kansas' cattle on feed are found in the southwestern part of the state. There also has been a trend toward large-scale concentrated animal feeding operations with a capacity of 1000 head or more. In southwestern Kansas, there are numerous feedlots, some with capacities that exceed 90,000 head.

$<$ Figure 1>

The growth of large-scale cattle feeding has, however, raised several serious environmental concerns. One of the broad areas of concern is water quality and the potential for contamination by animal waste generated in quantities that cannot be readily assimilated by the environment. This concern has only recently achieved noticeable attention in Kansas. In many parts of the US, the prospect of a nearby feedlot would bring protests based on odor problems and associated reductions in property values. Odor is an accepted aspect of cattle raising in southwestern Kansas, however: the long history and importance of cattle in the area has counteracted any local problems with "the smell." Locals sometimes refer to feedlot odors as "the smell of money."

An additional environmental concern with concentrated cattle feeding, and one not recognized by the general public, is its potential impact on climate change ('global warming'). Feedlot operations have been identified as an important, though localized, source of greenhouse gas emissions, particularly methane (e.g., Goodin et al. 1998) .

Global change and sustainability issues can be considered at a number of levels, and related to a variety of social and environmental conditions. Questions of scale (e.g., Cocklin et al. 1997), consideration of cultural factors (Proctor 1998), and the balance of environmental, economic and social considerations (e.g., Cocklin 1995) have been addressed, and both urban environments and rural/agricultural settings have been considered. Research and policy approaches toward local conditions, sustainability, and understanding of attitudes and perceptions that may affect actions toward sustainability are needed; national scale approaches can miss significant local variations. As has been noted, greenhouse gas emissions, potential effects, and possible responses vary from place to place, and mitigation must take place through local action (see, e.g., Agyeman et al. 1998, Dow 1992, Easterling et al. 1998, Kates and Torrie 
1998, Kates et al. 1998, Wilbanks and Kates 1999). To build understanding of global sustainability, potential local responses to various aspects of global change need to be considered.

In order to assess the potential for adaptation to possible climate change or for mitigation of greenhouse gas emissions, we must understand current views of entrepreneurs and the general public. Numerous studies have investigated public perceptions and attitudes toward climate change (Bord et al. 1998; Bord et al. 2000; Berk and Schulman 1995; Bostrom et al. 1994; Cutter et al. in press; Kempton 1991a, 1991b, 1997; Krosnick et al. 1998; O’Connor 1999; Read et al. 1994). Much attention has been paid to climate change and variability impacts on agriculture and potential agricultural adjustments to climate change, particularly related to crop farming (e.g., Chiotti and Johnston 1995, Easterling et al. 1993, Holloway and Ilbery 1997, IPCC 1996, IPCC 1998, Parry 1990, Rosenberg 1986, Rosenberg and Katz 1991, Rosenzweig and Hillel 1995, Smith and Tirpak 1989, Wall 1991), but relatively few researchers have addressed agriculturalists' perceptions of or attitudes toward climate change (Brklacich et al. 1997, Brklacich et al. 2000, Chiotti et al. 1997). Feedlot operations generally have received little attention related to global change concerns and sustainability. The purposes of this paper are to 1) provide an overview of the changing conditions of cattle production in the High Plains of Kansas and 2) analyze perceptions and attitudes of feedlot operators in southwestern Kansas concerning greenhouse gas emissions, climate change and related adaptive or mitigative measures.

\section{Confined Animal Feeding in Southwestern Kansas}

Livestock ranching has long been an important sector of the economy in southwestern Kansas and the Great Plains in general. In 1885, von Richthofen reported that early European settlers in the Great Plains soon recognized the region's favorable conditions for raising cattle. The beef produced there was shipped to the eastern states and Europe, especially feeding British demand (Rifkin 1992). Von Richthofen asserted that the region "will probably soon become the most important beef-producing country of the globe" (1885, p. 5). His prediction has become a reality, largely due to the major geographic transformation in the livestock industry that started in the 1960s (Bussing and Self 1981, Drabenstott et al. 1999, Raup 1986).

Cattle-feeding moved out of the Corn Belt and has increasingly concentrated in the southern Great Plains, particularly in the High Plains of Texas, Kansas, and Oklahoma (Hart and Mayda 1998). Climate conditions (low humidity and high evaporation rates) help to minimize animal disease concerns, and there has been a ready supply of feed grains. When refrigerated trucks increased ease of transportation for meat products, the beef packing industry followed livestock herds (Drabenstott, et al. 1999). Shipping prices dropped in the 1960s, and abundant feed grain was available in southwestern Kansas and the Texas panhandle, leading to an increase in meat packing capacity in the High Plains from 400,000 to 2.6 million head between 1960 and 1969 (Hart 1998). The extent of concentration has led to reference to the High Plains as "The Beef Belt."1

The way cattle are fed also has changed significantly since von Richthofen's time. Traditionally, most cattle were grass-fed before slaughter, with only a small proportion fed grain. Today, most animals are fed in confined spaces to complete the growing-finishing process in order to produce meat that is of higher quality and more uniform grades (Bussing and Self 1981). They may begin life in more traditional pasturage, but are transferred to 
feedlots or feedyards at 550 to 750 pounds, and are fed until they reach slaughter weight of 1050 to 1300 pounds (White 2001). Corn or sorghum generally makes up the bulk of the feed, with a variety of supplements included (e.g., protein concentrates, high energy feeds, other additives).

Commercial feedlots emerged during WWII and now dominate the livestock production (Saito and Yagasaki 1998). Cattle-feeding operations are particularly concentrated and intensive in Southwest Kansas and the neighboring Texas and Oklahoma panhandle areas. The number of cattle on feed in Kansas has risen steadily over the last few decades (Figure 2). Well over half of Kansas' cattle on feed are found in the southwestern part of the state (Kansas Agricultural Statistics Service 2001). ${ }^{2}$ There also has been a trend toward large-scale feedlots or feedyards, with capacities reaching several tens of thousands of head.

$<$ Figure 2>

In southwestern Kansas there are a large number of feedlots, concentrated animal feeding operations (CAFOs) with a capacity of 1000 head or more (Table 1). The top three feedlots in Kansas are all in this area: Grant County Feedyard in Ulysses (112,000-head capacity), Cattle Empire Feedyard in Sublette (108,000 head), and Caprock Industries in Leoti (98,000 head).

$<$ Table 1>

With the consolidation in the livestock industry in the last few decades, the cattlecentered regional economy in southwestern Kansas has moved increasingly toward vertical integration. Groundwater from the Ogallala Aquifer supports high-yielding feed grain production, which in turn supports a thriving feedlot industry. The large number of fed cattle and available high-quality groundwater helped attract beef packing plants to the region (Broadway 2000). Five major beef packing plants exist in the region: IBP in Holcomb, ConAgra in Garden City, Excel and Farmland Industries in Dodge City, and Farmland Industries (National Beef) in Liberal. The ConAgra facility in Garden City was largely destroyed by fire in December 2000, however. When or whether the plant will reopen still is unknown.

The industrialization of agriculture in more developed countries has become increasingly pronounced, with a move toward larger and more corporatized operations with potentially large environmental impacts especially noticeable with livestock 'factory farming' operations (see Furuseth 1997, Ilbery et al. 1997). Environmental scientists raise the issues of both waste management and greenhouse gas releases. The large-scale cattle feeding industry in Southwest Kansas is associated with serious concerns related to global change. Agricultural restructuring also is related to economies of scale and the growth of large international agricultural corporations. Impacts on smaller operators' ability to compete also have been noted. Locals and social scientists are concerned with continued vertical integration and increasing size of operations, with concomitant reductions in smaller operators. Sustainability of the socio-economic system of southwestern Kansas also comes into question, particularly given dependence on the Ogallala aquifer (Kromm and White 1992).

With respect to global climate change, it has been estimated that ruminants produce an average of about $3.7 \mathrm{~kg}$ of methane per day (USEPA 1995, cited in Goodin et al. 1998) by enteric fermentation. Even more is produced by the breakdown of manure, but the amount varies greatly with manure management and climate. Methane is a more effective greenhouse 
gas than carbon dioxide, with 20 times the heat trapping capacity on a per molecule basis. "Domestic animals account for approximately $94 \%$ of total global methane emissions by animals (including humans)," and cattle produce $70 \%$ of animal emissions (Milich 1999). The total amount of greenhouse gas emissions by all the cattle in the region is substantial. For a six county area of southwestern Kansas, covering about $14,000 \mathrm{~km}^{2}$, it has been calculated that the respiration from the 1990 cattle population (over 900,000 head) emitted the carbon-equivalent of respiration from about 4.5 million people (Harrington 2001a). A questionnaire-based survey of feedlot operators in this area was conducted in late 1998 in order to obtain information about feedlot operators' perceptions of, and attitudes toward, global warming and livestock industry change. Finney, Ford, Gray, Haskell, Meade and Seward counties comprise an area of intensive animal-feeding operations (Figure 3).

$<$ Figure 3>

All feedlots of at least 1000 head capacity were included in the sample but their capacities ranged from a few thousand head to several tens of thousands of head. Of 55 questionnaires mailed, 24 usable responses were returned, yielding a response rate of $44 \%$. Although this is a relatively small total number of responses, it does represent over $40 \%$ of the area's CAFOs. A separate household survey was also carried out for comparison, which resulted in 199 valid returns out of the 702 households contacted (Table 2) (Harrington 2001b). In addition to the mailed surveys, both feedlot representatives and others knowledgeable about the industry in southwestern Kansas were interviewed at various times in 1997, 1998, and 2000. Key informant interviews help to inform further discussion about change and sustainability in this part of the High Plains.

\section{Views on Global Warming}

$<$ Table 2>

Feedlot operators generally did not believe that global warming associated with fossil fuel burning has been proven. A majority (58\%) of the respondents believed that global warming is mostly an unproven theory; only one respondent thought that global warming is a proven fact (Table 3). In contrast, among respondents to the household survey, 29\% indicated a belief that global warming is unproven and $21 \%$ indicated that it is mostly proven fact. So, while the general southwestern Kansas public was divided on the issue, feedlot operators displayed much more agreement that there is a lack of proof that global warming as a result of fossil fuel use can be expected .

$<$ Table 3>

Some feedlot operators had fairly strong opinions about the whole concept, as reflected in the following comment:

\section{I do not believe that the greenhouse effect is anything more than a figment of educated idiots imagination.}

Others felt that even if global warming is happening, human activities such as cattle-raising are not the cause. For example,

If global warming is a result of "Greenhouse Gas Emission," mankind's contribution is infinitesimal compared to natural plant evolution, volcanoes, etc. 
It is my opinion animals have very little to do with greenhouse gas or global warming.

Similar to responses about global warming 'theory,' when asked how serious a problem climate changes are likely to be, half the feedlot operators felt that global warming will be 'no problem at all' in the next 50-100 years (Table 4). Only 15\% of the household respondents held the same view. A much larger proportion of household respondents than of feedlot operators considered climate changes a potentially serious problem $(57.8 \%$ vs. $12.5 \%$ as 'pretty,' 'very,' or 'extremely' serious). The US public as a whole has been found to have fairly strong concerns about climate change (Krosnick et al. 1998), generally surpassing those in southwestern Kansas (Harrington 2001b). More recently, a March 2001 Time/CNN poll found $43 \%$ of respondents rating global warming as 'very serious,' $32 \%$ rating it 'fairly serious,' $14 \%$ rating it 'not very serious,' and 7\% rating it as 'not at all serious.' This poll, however, was done near the time of the release of the third IPCC and National Academy of Sciences reports on climate change, and so potentially was during a period of increased public awareness. On the other hand, the southwestern Kansas feedlot survey took place during a period of relatively strong negative publicity regarding the Kyoto global warming conference.

\section{$<$ Table 4>}

Consistent with their views on global warming, very few feedlot operators thought global warming would have a great or considerable impact on their own or their grandchildren's lives (Table 5). In comparison, while only a small percentage of household respondents felt global warming will significantly affect them during their own lifetime, over half of them believed it will have great or considerable effect on their grandchildren (51.2\%); only $8.4 \%$ of feedlot operators thought that their grandchildren would experience a great or considerable effect from global warming. A quarter of feedlot operators believed global warming will have very little effect on their grandchildren. The corresponding proportion of household respondents was only $10 \%$.

\section{$<$ Table 5>}

Both feedlot operator and household respondents were also asked about the effects of global warming for southwestern Kansas (Table 6). A large proportion of both groups (45.8\% of feedlot operators and $40 \%$ of household respondents) responded that they did not know. There again was a contrast between the two groups, however, with $16.7 \%$ of feedlot operators and $36.7 \%$ of household respondents indicating that global warming would have negative effects for southwestern Kansas.

$<$ Table 6>

Feedlot operators seemed not sure about who should take the responsibility for reducing greenhouse gas emissions or they may not be willing to assign responsibility. When asked a question addressed in a National Academy of Sciences (1992, 687) study, "who should be responsible for the reduction of greenhouse gas emissions," feedlot representatives believed that local and federal government should be least responsible for greenhouse gas reductions (Table 7). Government intervention in general is not positively regarded in the region. One respondent ranked all categories at '5,' indicating a lack of belief that anyone should be responsible. This would reasonably coincide with a belief that there is no reason to address 
climate change concerns. At least some of those not responding to this question also may have been opposed to any assignment of responsibility for greenhouse gas reductions.

$<$ Table 7>

\section{Mitigative and Adaptive Actions}

The likelihood of some human-induced climate change through greenhouse gas emissions is now widely accepted in the scientific community (IPCC 2001). One possible response to environmental change is to adapt: to implement social and economic changes that tend to minimize negative impacts without necessarily doing anything directly to slow or halt the environmental change itself (e.g., shading animals in a feedyard to minimize heat stress production losses). Adaptation sometimes is seen as the reasonable response to climate change, especially when the assumption is made that change will happen fairly gradually (Kates 1997). Another response is to take actions that reduce, or mitigate, environmental change by manipulating the level of direct human contributions to environmental change. Mitigation of human-induced climate change would include direct actions to reduce greenhouse gas emissions (e.g., modifying the feed mix to reduce methane emissions from enteric processes) and actions to increase carbon sequestration through land cover change. A third possibility is, of course, the 'do nothing' option, or 'business as usual' (Houghton 1997, Watson et al. 1996a, Parker and Blodgett 1998) frequently included in planning documents and scenarios. Mitigative actions are considered desirable, but adaptation also is a likely future necessity (Parry et al. 1999).

In the livestock industry, some methods have been developed that can reduce methane releases, including changes in feeding practices and waste handling, and there are also techniques that can be used for methane capture from waste lagoons. But these measures have rarely been used in the study area. Only one of the 24 respondents in our feedlot survey indicated that his company had taken action to reduce greenhouse gas emissions. In that case the actions taken included solid material distribution and decomposition as well as wastewater distribution. One respondent mentioned covering cattle waste lagoons, as required in the neighboring state of Colorado, as a way to reduce emissions, but another feedlot operator felt that the cost of covering lagoons is prohibitive. Reducing fossil fuel usage in feeding operations is another way of decreasing greenhouse gas emissions. Feedlots in the study area have adopted some actions to reduce energy use, but mostly to lower operating costs, rather than to help the environment. One feeding company uses a wind turbine for a portion of its electricity needs, which helps the company to avoid a peak energy use surcharge. Another feedlot representative also indicated the need for greater development of local wind power.

An interesting result of this study is that although strong doubts existed among the feedlot operators about climate change, there was some support for actions to reduce the threat of global warming. Some feedlot operators are willing to pay some additional money to reduce global warming. The percent of operators in favor of paying some additional costs to reduce global warming is fairly persistent, including $25 \%$ for $\$ 85$, about $21 \%$ for $\$ 250,21 \%$ for $\$ 500$, and $25 \%$ for $\$ 1000$. At least one third of the respondents, however, opposed any additional cost, and not surprisingly opposition rose as the cost increased (Table 8). This differs from a conclusion reached by Bord et al. (1998) that "[r]ecent polls that include global warming as a specific issue have continued to find majorities [in the US] indicating a willingness to pay to reduce its impacts.” Expressed willingness to pay differs, however, depending on the framing 
of the question: a March 2001 Time/CNN poll found that support for government actions to reduce global warming was 54\% for and 39\% against, if associated with a mild increase in inflation; $47 \%$ for and $49 \%$ against, if it meant a utility bill increase; and 38\% for and 55\% against, if unemployment increased.

$<$ Table 8>

\section{Perceived Changes and Potential Stress in the Feedlot Industry}

According to several projections, climate outlooks for southwestern Kansas under global warming are for warmer temperatures and reduced effective annual precipitation (NAST 2000). Feedlot operators were asked about potential adaptive reactions should such climate change occur. Possible adaptations included expanding shaded areas, increasing water availability, change to more heat-adapted cattle breeds, use of sprinklers or misting devices to help cool animals, moving to another region, reducing cattle density in pens, and building cooled barns. On a scale of 1 to 5, with 1 being most likely, respondents indicated the most likely adaptation would be through increasing water availability to animals ( 2.3 ave response). Moving to another region and building air-conditioned or evaporatively-cooled barns are seen as least likely (4.5 ave response). The other options were rated as neither likely nor unlikely, with average responses near 3 .

Feedlot operators in southwestern Kansas have described the growth of feedlots in recent years, and expressed expectations that feedlot operations will continue to enlarge and become increasingly 'vertically integrated' (Table 9). One respondent noted the loss of smaller farmer/feeders in conjunction with the move toward larger and larger operations. An increasing role for technology and genetics, greater efficiency, and expected greater regulation also were noted.

$<$ Table 9>

The concomitant growth of mega-meatpacking operations with the growth of CAFOs has drawn criticism for social and environmental reasons (Broadway 2000). Feedlot operators, however, perceive the likelihood of continued growth of operations in southwestern Kansas, even though some potentially negative consequences (continued loss of small farmer and feeder operations) are likely. It also is sometimes argued that large operations have more economic wherewithal to address environmental problems and meet regulatory obligations.

\section{Discussion and Conclusions}

Agriculturalists, in general, are expected to need to adapt to climate change; some studies already have been conducted to assess farmers' climate perceptions and adaptation strategies on other parts of the continent (Brklacich et al. 1997, Brklacich et al. 2000, Chiotti et al. 1997). Global change describes broad shifts in socio-economic systems, as well as biophysical change, however, and agriculture also must contend with industrialized trends toward larger scale operations and greater vertical integration. In southwestern Kansas, feedlot operators and others are quite aware of the broad international economics of the industry and local stresses that can arise from closure of packing plants, local environmental concerns (groundwater depletion and water quality, e.g.), and pressures that create greater vertical integration and fewer small operators. With immediate and locally visible beef production concerns, a more nebulous issue like climate change or global warming is not a major issue. This contrasts with the general public of southwestern Kansas, which expressed greater concern with climate change, and contrasts even more with the national public. 
What factors might have shaped the views of the feedlot operators is not clear. It is possible that exposure to Fall 1998 television advertisements that opposed ratifying the Kyoto protocol may have affected their thinking. Those advertisements emphasized the point that the protocol permits some large greenhouse gas-producing developing countries to continue high emissions levels, and claimed that emission reductions without worldwide participation would harm the U.S. economy. It is most likely that day-to-day economic considerations-generally the foremost concern of any agribusiness-coupled with doubts about the reality of climate change, were and are important factors in feedlot operators' attitudes.

Legislators from Kansas recently have been addressing the issue of global warming, promoting carbon sequestration by no-till farming and soil carbon research. Such advocation of agricultural activities to address greenhouse gas emissions may lead to greater acceptance of climate change ideas in some agricultural sectors, but it may not extend to animal feeding.

The results of this study show that climate change is not a major concern among feedlot operators in this rural area of Kansas. Though there is some belief that the global climate change issue is real, individuals accepting climate change are a minority. To some, 'global warming' is a real concern or an interesting subject. To others, it is unproven and only an issue if the concept results in increased costs from mandated mitigative actions. One respondent criticized environmental regulation by (exaggeratedly) stating that "The change [in the cattle industry] is somewhat due to cost of greenhouse compliance.” Feedlot respondents do not see their industry as contributors either to a problem or to a solution. They work with a fairly narrow profit margin, and any voluntary mitigative actions would have to pay for themselves.

Responses indicate that a perceptual contrast between the general public and representatives of the cattle feeding industry is evident. The general population displays a higher level of concern with climate change than do feedlot operators. Research by O’Connor and others (1999) has shown that "risk perceptions and knowledge increase people's willingness to take steps that address environmental problems." Since global warming is not generally perceived as an issue, virtually no direct adaptive or mitigative measures have been taken in animal feeding operations in southwestern Kansas. Any actions that might have been taken were adopted for economic reasons, and any greenhouse gas reductions are an indirect benefit. Compounding the issue is that skepticism about global warming among many of the respondents seems firmly entrenched. Some feedlot operators are willing to pay some additional cost to reduce global warming even with the widespread skepticism. They may also take adaptive measures if the climate in the region indeed becomes warmer and drier as predicted by some climate models. The most likely adaptive measure indicated on surveys, however, was water-dependent: to increase water usage to mitigate the effects of climate change. Since the depletion of groundwater from the Ogallala Aquifer is itself a major concern for the region, balancing multiple risks in the short and long term could be difficult.

The feedlot industry in Southwest Kansas is undergoing continued change. Although local manifestations of global change, seen in resource depletion and restructuring of agriculture through enterprise growth and vertical integration, are of concern to people in the region, mitigation of global change as it may be manifested in climate systems has not achieved the same attention.

\section{Notes}


${ }^{1}$ Territorial Magazine (21[2]:20-24) 2001 report on Beef Empire Days. The report also listed 80 feedyards for the Kansas High Plains, many of which are in southwestern Kansas.

${ }^{2}$ Southwest Kansas is comprised of the following 14 counties: Clark, Finney, Ford, Grant, Gray, Hamilton, Haskell, Hodgeman, Kearny, Meade, Morton, Seward, Stanton, and Stevens.

3 “Proposal approved for Garden City feedyard,” Kansas State Collegian 30 August 2000.

\section{References}

Agyeman, J, Evans, B. and Kates, R.W., 1998. Editorial: Greenhouse gases special: Thinking locally in science, practice and policy. Local Environment 3(3), 245-246.

Berk, R.A. and Schulman, D., 1995. Public perceptions of global warming. Climate Change 29,133.

Bord, R.J., Fisher, A. and O’Connor, R.E. 1998. Public perceptions of global warming: United States and international perspectives. Climate Research 11,75-84.

Bord, R.J., O’Connor, R.E. and Fisher, A., 2000. In what sense does the public need to understand global climate change? Public Understanding Science 9,205-218.

Bostrom A., Morgan, M.G., Fischoff, B. and Read, D., 1994. What do people know about global climate change? 1. Mental models. Risk Analysis 14(6),959-970.

Brklacich, M., Bryant, C., Veenhof, B. and Beauchesne, A., 2000. Agricultural adaptation to climatic change: A comparative assessment of two types of farming in central Canada. P. 40-51 in Agricultural \& Environmental Sustainability in the New Countryside. H. Millward, K. Beesley, B. Ilbery, and L. Harrington, eds. St. Mary’s University, Halifax.

Brklacich, M., McNabb, D., Bryant, C. and Dumanski, J., 1997. Adaptability of agricultural systems to global climate change: A Renfrew County, Ontario, Canada pilot study. P. 185200 in Agricultural Restructuring and Sustainability. B. Ilbery, Q. Chiotti, and T. Rickard, eds. CAB International, Wallingford.

Broadway, M.J., 2000. Kansas’ Booming Beef Industry. Kansas Business Review 23(3),22-30.

Broadway, M.J., 2000. Planning for change in small towns or trying to avoid the slaughterhouse blues. Journal of Rural Studies 16,37-46.

Bussing, C.E. and Self, H., 1981. Changing Structure of the Beef Industry in Kansas. Transactions of the Kansas Academy of Sciences 84(4),173-186.

Chiotti, Q.P. and Johnston, T. 1995. Extending the boundaries of climate change research: A discussion on agriculture. Journal of Rural Studies 11(3),335-350.

Chiotti, Q., Johnston, T., Smit, B. and Ebel, B., 1997. Agricultural response to climate change: A preliminary investigation of farm-level adaptation in southern Alberta. P. 201-218 in Agricultural Restructuring and Sustainability. B. Ilbery, Q. Chiotti, and T. Rickard, eds. CAB International, Wallingford.

Cocklin, C., 1995. Agriculture, society and environment: Discourses on sustainability. International Journal of Sustainable Development and World Ecology 2,240-256.

Cocklin, C., Blunden, G. and Moran, W., 1997. Sustainability, spatial hierarchies and land-based production. P. 25-39 in Agricultural Restructuring and Sustainability. B. Ilbery, Q. Chiotti, and T. Rickard, eds. CAB International, Wallingford.

Cutter, S.L., Mitchell, J.T.. Hill, A., Harrington, L., Kaktins, S., Muraco, B., DeHart, J., Reynolds, A. and Shudak, R., in press. Attitudes toward reducing greenhouse gas emissions from local places. Association of American Geographers Global Change and Local Places Research 
Team. Global Change and Local Places: Estimating, Understanding, and Reducing Greenhouse Gases. Cambridge University Press, Cambridge.

Dow, K., 1992. Exploring differences in our common future(s): The meaning of vulnerability to global environmental change. Geoforum 23(3),417-436.

Drabenstott, M., Henry, M. and Mitchell, K., 1999. Where have all the Packing plants gone? The new meat geography in rural America. Economic Review (Federal Reserve Bank of Kansas City) Third Quarter, 65-82.

Easterling, W.E., Crosson, P.R., Rosenberg, N.I., McKenney, M.S., Katz, L.A. and Lemon, K.M., 1993. Agricultural impacts of and responses to climate change in the Missouri-IowaNebraska-Kansas (MINK) region. Climatic Change 24,23-61.

Easterling, W.E., Polsky, C., Goodin, D., Mayfield, M.W., Muraco, W.A. and Yarnal, B., 1998. Changing places, changing emissions: the cross-scale reliability of greenhouse gas emission inventories in the US. Local Environment 3(3),247-262.

Furuseth, O.J., 1997. Sustainability issues in the industrialization of hog production in the United States. In: Ilbery, B., Chiotti, Q., Rickard, T. (Eds.), Agricultural Restructuring and Sustainability: A Geographical Perspective. CAB International, Wallingford.

Goodin, D.G., Harrington, J.A., Holden, G.I. and Witcher, B.D.. 1998. Local greenhouse gas emissions in southwestern Kansas. Great Plains Research 8,231-53.

Harrington, J.A., 2001a. Personal communication. (Re: 'Global Change in Local Places’ research project findings)

Harrington, L.M.B., 2001b. Attitudes toward climate change: Major emitters in southwestern Kansas. Climate Research 16(2),113-122.

Hart, J.F., 1998. The Rural Landscape. Johns Hopkins University Press, Baltimore.

Hart, J.F. and Mayda, C., 1998. The industrialization of livestock production in the United States. Southeastern Geographer 38(1),58-78.

Holloway, L.E. and Ilbery, B.W., 1997. Global warming and navy beans: Decision making by farmers and food companies in the U.K. Journal of Rural Studies 13(3),343-355.

Houghton, J., 1997. Global Warming: The Complete Briefing. $2^{\text {nd }}$ ed. Cambridge University Press, Cambridge.

Ilbery, B., Chiotti, Q., Rickard, T. (Eds.), 1997. Agricultural Restructuring and Sustainability: A Geographical Perspective. CAB International, Wallingford.

Intergovernmental Panel on Climate Change (IPCC), Working Group II, 1996. Climate Change 1995. Impacts, Adaptations and Mitigation of Climate Change: Scientific-Technical Analyses. R.T. Watson, M.C. Zinyowera, R.H. Moss and D.J. Dokken, eds. Cambridge University Press, Cambridge.

Intergovernmental Panel on Climate Change (IPCC), Working Group I, 2001. Climate Change 2001: The Scientific Basis. J. Houghton, Y. Ding, D.J. Griggs, M. Noguer, P.J. van der Linden, X. Dai, K. Maskell and C.A. Johnson, eds. Cambridge University Press, Cambridge.

Intergovernmental Panel on Climate Change (IPCC), 1998. The Regional Impacts of Climate Change: An Assessment of Vulnerability. R.T. Watson, M.C. Zinyowera, R.H. Moss and D.J. Dokken, eds. Cambridge University Press, Cambridge.

Kansas Agricultural Statistics Service, 2001 Kansas Farm Facts. Kansas Department of Agriculture, Topeka. Http://www.nass.usda.gov/ks/ffacts/2001/ 
Kates, R.W., 1997. Climate Change 1995: Impacts, Adaptations, and Mitigation (review). Environment 39(9),29-33.

Kates, R.W., Mayfield, M.W., Torrie, R.D., Witcher, B., 1998. Methods for estimating greenhouse gases from local places. Local Environment 3 (3), 279-297.

Kates R.W. and Torrie, R.D., 1998. Global change in local places. Environment 40(2),5,39-41.

Kempton, W., 1997. How the public views climate change. Environment 39(9),12-21.

Kempton, W., 1991a. Lay perspectives on global climate change. Global Environmental Change 1(3),183-208.

Kempton, W., 1991b. Public understanding of global warming. Society and Natural Resources 4,331-345.

Kromm, D.E. and White, S.E., eds., 1992. Groundwater Exploitation in the High Plains. University Press of Kansas, Lawrence.

Krosnick, J.A., Visser, P.S. and Holbrook, A.L., 1998. American opinion on global warming: The impact of the fall 1997 debate. Resources 133,5-9.

Milich, L., 1999. The role of methane in global warming: Where might mitigation strategies be focused? Global Environmental Change 9,179-201.

National Academy of Sciences (NAS), 1992. Policy implications of greenhouse warming: Mitigation, adaptation, and the science base. National Academy Press, Washington.

National Agricultural Statistics Service (NASS), 1999. Cattle: Final Estimates 1994-98. Statistical Bulletin Number 953. US Department of Agriculture, Washington. Http://usda.mannlib.cornell.edu/reports/nassr/livestock/pct-bbc/2001/

National Agricultural Statistics Service (NASS), 1997. 1997 Census of Agriculture. Volume 2. Subject Series: National Atlas. US Department of Agriculture, Washington. Http://www.nass.usda.gov/census/census97/atlas97/

National Assessment Synthesis Team (NAST), 2000. Climate Change Impacts on the United States: The Potential Consequences of Climate Variability and Change. US Global Change Research Program, Washington. Http://www.gcrio.org/ NationalAssessment

O’Connor, R.E., Bord, R.J. and Fisher, A., 1999. Risk perceptions, general environmental beliefs, and willingness to address climate change. Risk Analysis 19(3),461-471.

Parker, L. and Blodgett, J., 1998. Global climate change: Reducing greenhouse gases-how much from what baseline? Congressional Research Service Report for Congress. 98-235 ENR. 11 Mar. Http://www.cnie.org/nle/clim-13.html.

Parry, M., 1990. The potential impact on agriculure of the greenhouse effect. Land Use Policy 7(2), 109-123.

Parry, M., Arnell, N., Hulme, M., Martens, P., Nicholls, R. and White, A., 1999. Viewpoint-the global impact of climate change: A new assessment. Global Environmental Change 9:S1S2.

Proctor, J.D., 1998. The meaning of global environmental change: Retheorizing culture in human dimensions research. Global Environmental Change 8(3),227-248.

Raup, P.M., 1986. The Future of The Missouri Livestock Industry: Summary of the Seminar. Staff Paper P86-55. Department of Agricultural and Applied Economics, The University of Minnesota. 
Read, D., Bostrom, A., Morgan, M.G., Fischoff, B. and Smuts, T., 1994. What do people know about global climate change? 2. Survey studies of educated lay people. Risk Analysis 14(6),971-982.

Rifkin, J., 1992. Beyond Beef. Dutton, New York.

Rosenberg, N.J., 1986. Adaptations to adversity: Agriculture, climate, and the Great Plains of North America. Great Plains Quarterly 6,202-217.

Rosenzweig, C., and Hillel, D., 1995. Potential impacts of climate change on agriculture and food supply. Consequences 1(2),23-32.

Rosenberg, N.J. and Katz, L.A., 1991. Climate variability and Great Plains agriculture. Symposium on the Impacts of Climatic Change and Variability on the Great Plains. Occasional Paper No. 12. Wall, Geoffrey, ed. Department of Geography, University of Waterloo, Waterloo.

Saito, I. and Yagasaki, N., 1998. Development of Cattle Feedlots and Vertical Integration of Beef Industry in the American High Plains. Journal of Geography (Japan) 107(5),674-694.

von Richthofen, W.B., 1885 (1964 reprint). Cattle-raising on the Plains of North America. University of Oklahoma Press, Norman.

Smith, J.B. and Tirpak, D., eds., 1989. Chapter 17: Great Plains. In The Potential Effects of Global Climate Change on the United States. Report to Congress. Office of Policy, Planning, and Evaluation, US Environmental Protection Agency, Washington.

United States Environmental Protection Agency (USEPA), 1995. State Workbook: Methodologies for Estimating Greenhouse Gas Emissions. EPA-B-95-001. USEPA Office of Policy, Planning, and Evaluation, Washington.

Wall, Geoffrey, ed. 1991. Symposium on the Impacts of Climatic Change and Variability on the Great Plains, Occasional Paper No. 12. Department of Geography, University of Waterloo, Waterloo.

Watson, R.T., Zinyowera, M.C. and Moss, R.H., eds., 1996. Climate change 1995: Impacts, adaptations and mitigation of climate change: Scientific-technical analyses. The Second Assessment Report of the Intergovernmental Panel on Climate Change. Cambridge University Press, Cambridge

White, D., 2001. Cattle feeding 101. Cattle Today. Http://www.cattlefeeding.com/ cattle_feeding_101.htm

Wilbanks T.J. and Kates, R.W., 1999. Global change in local places: How scale matters. Climate Change 43(3),601-628. 
Table 1. Top states with cattle and calves on feed.

\begin{tabular}{|l|r|r|r|}
\hline & Total on Feed 1-1998 & \multicolumn{2}{|c|}{ Number of Operations 1997} \\
\hline Texas & \multicolumn{1}{|c|}{ Head } & Cap. $\geq 1000$ & Cap. $\geq 16000$ \\
\hline Kansas & $2,860,000$ & 1300 & 73 \\
\hline Nebraska & $2,370,000$ & 600 & 58 \\
\hline Colorado & $2,300,000$ & 950 & 32 \\
\hline Iowa & $1,140,000$ & 400 & 19 \\
\hline Oklahoma & $1,000,000$ & 350 & - \\
\hline California & 435,000 & 500 & 12 \\
\hline
\end{tabular}

(Source: NASS 1999)

Table 2. Survey mailings.

\begin{tabular}{|l|c||c|}
\hline & Feedlot Survey & Household Survey \\
\hline \hline Number Mailed & 55 & 702 \\
\hline Number Deliverable & 55 & 584 \\
\hline $\begin{array}{l}\text { Usable Response Rate } \\
\text { (based on deliverable) }\end{array}$ & $44 \% \quad(\mathrm{n}=24)$ & $34 \% \quad(\mathrm{n}=199)$ \\
\hline
\end{tabular}

Table 3. Would you say that it is mostly a proven fact that burning oil, coal, and natural gas for energy will cause global warming in the future, or that it is mostly an unproven theory?

\begin{tabular}{|l|c|c|c|c|}
\hline & \multicolumn{4}{|c|}{ Percent } \\
\hline Respondents & $\begin{array}{c}\text { mostly an } \\
\text { unproven } \\
\text { theory }\end{array}$ & $\begin{array}{c}\text { mostly a } \\
\text { proven } \\
\text { fact }\end{array}$ & $\begin{array}{c}\text { somewhere between } \\
\text { unproven speculation } \\
\text { and proven fact }\end{array}$ & $\begin{array}{c}\text { other/ } \\
\text { don't know/NR }\end{array}$ \\
\hline feedlot $(\mathrm{n}=24)$ & 58.3 & 4.2 & 29.2 & 8.3 \\
\hline \hline households $(\mathrm{n}=199)$ & 28.6 & 21.1 & 30.7 & 19.6 \\
\hline
\end{tabular}

$\mathrm{NR}=$ not responding 
Table 4. Some people think climate changes caused by global warming will be a serious problem for the world in the next 50-100 years if no action is taken; others disagree. How serious a problem do you think such climate changes are likely to be?

\begin{tabular}{|l|c|c|c|c|c|c|}
\hline & \multicolumn{7}{|c|}{ Percent } \\
\hline Respondents & $\begin{array}{c}\text { no problem } \\
\text { at all }\end{array}$ & $\begin{array}{c}\text { slightly } \\
\text { serious }\end{array}$ & $\begin{array}{c}\text { pretty } \\
\text { serious }\end{array}$ & $\begin{array}{c}\text { very } \\
\text { serious }\end{array}$ & $\begin{array}{c}\text { extremely } \\
\text { serious }\end{array}$ & NR \\
\hline feedlot (n=24) & 50.0 & 37.5 & 4.2 & 8.3 & 0 & 0 \\
\hline \hline household (n=199) & 14.6 & 25.1 & 31.7 & 20.6 & 5.5 & 2.5 \\
\hline
\end{tabular}

Table 5. How much, if at all, would global warming affect you in your lifetime? / your grandchildren in their lifetime?

\begin{tabular}{|l|l|c|c|c|c|c|}
\hline & & \multicolumn{5}{|c|}{ Percent } \\
\hline \multirow{2}{*}{ Respondents } & & $\begin{array}{c}\text { a great } \\
\text { amount }\end{array}$ & $\begin{array}{c}\text { a } \\
\text { considerable } \\
\text { amount }\end{array}$ & somewhat & $\begin{array}{c}\text { dery } \\
\text { little }\end{array}$ & $\begin{array}{c}\text { know/ } \\
\text { NR }\end{array}$ \\
\hline \multirow{2}{*}{$\begin{array}{l}\text { feedlot } \\
(\mathrm{n}=24)\end{array}$} & Own lifetime & 0 & 4.2 & 8.3 & 70.8 & 16.7 \\
\cline { 2 - 8 } & $\begin{array}{l}\text { Grandchildren's } \\
\text { lifetime }\end{array}$ & 4.2 & 4.2 & 25.0 & 25.0 & 41.7 \\
\hline \hline $\begin{array}{l}\text { household } \\
(\mathrm{n}=199)\end{array}$ & Own lifetime & 3.5 & 12.1 & 35.7 & 28.6 & 20.1 \\
\cline { 2 - 8 } & $\begin{array}{l}\text { Grandchildren's } \\
\text { lifetime }\end{array}$ & 26.6 & 24.6 & 12.6 & 10.1 & 26.1 \\
\hline
\end{tabular}

Table 6. Overall, would you say that the effects of global warming for southwestern Kansas would be:

\begin{tabular}{|l|c|c|c|c|}
\hline & \multicolumn{4}{|c|}{ Percent } \\
\hline Respondents & good & bad & neither good nor bad & don't know/NR \\
\hline feedlot $(\mathrm{n}=24)$ & 4.2 & 16.7 & 29.2 & 50.0 \\
\hline \hline household $(\mathrm{n}=199)$ & 2.5 & 36.7 & 19.6 & 40.7 \\
\hline
\end{tabular}


Table 7. Please rank the following responses from 1 to 5 , with 1 being most responsible and 5 being least responsible: Who should be responsible for the reduction of greenhouse gases?

\begin{tabular}{|l|r|r|r|r|r|}
\hline & \multicolumn{5}{|c|}{ Average rating } \\
\hline & $\begin{array}{r}\text { individual } \\
\text { households }\end{array}$ & businesses & $\begin{array}{r}\text { local } \\
\text { government }\end{array}$ & $\begin{array}{r}\text { state } \\
\text { government }\end{array}$ & $\begin{array}{r}\text { federal } \\
\text { government }\end{array}$ \\
\hline feedlots $(\mathrm{n}=17)$ & 2.6 & 2.5 & 3.4 & 3.1 & 3.4 \\
\hline
\end{tabular}

Notes: The respondents who only marked an option with an ' $\mathrm{X}$ ' are considered non-responses. Those who used a ranking number are included, even if they ranked multiple choices at the same level.

Table 8. Spending money to develop alternate energy technologies may help reduce future humanrelated climate change. Would you favor or oppose a program that would work to reduce future global warming if it cost your business operation any of the following amounts in extra taxes and higher energy prices each year:

\begin{tabular}{|c|c|c|c|c|c|}
\hline & \multicolumn{5}{|c|}{ Feedlot Respondents--Percentage } \\
\hline amount & favor & oppose & $\begin{array}{c}\text { neither favor } \\
\text { nor oppose }\end{array}$ & $\begin{array}{c}\text { don't } \\
\text { know }\end{array}$ & NR \\
\hline$\$ 85$ & 25.0 & 33.3 & 8.3 & 20.8 & 12.5 \\
\hline$\$ 250$ & 20.8 & 33.3 & 12.5 & 20.8 & 12.5 \\
\hline$\$ 500$ & 20.8 & 37.5 & 8.3 & 20.8 & 12.5 \\
\hline$\$ 1000$ & 25.0 & 45.8 & 4.1 & 16.7 & 8.3 \\
\hline$\$ 5000$ & 8.3 & 54.2 & 16.7 & 8.3 & 12.5 \\
\hline
\end{tabular}


Table 9. Changes noted by feedlot operators in southwestern Kansas.

\begin{tabular}{|c|c|c|}
\hline $\begin{array}{l}\text { What changes are taking place in the cattle } \\
\text { feeding industry? }\end{array}$ & $\begin{array}{l}\text { What changes have taken } \\
\text { place in this feedlot in the } \\
\text { last } 5 \text { years? [1994-98] }\end{array}$ & $\begin{array}{l}\text { What changes do you } \\
\text { expect in the next } 5 \\
\text { years? [1999-2003] }\end{array}$ \\
\hline $\begin{array}{l}\text {-Vertical integration } \\
\text {-Marketing changes } \\
\text {-More custom feeding } \\
\text {-More consolidation of feedlot ownership \& } \\
\text { cattle } \\
\text {-More economical; providing safer product; } \\
\text { more consolidation } \\
\text {-Concentration of cattle feeding entities... } \\
\text { - Move to larger feedlots, smaller farmer/feeders } \\
\text { quit } \\
\text {-Better genetics for reproduction, efficiency, } \\
\text { quality of digestible product; improved feeding } \\
\text { equipment/technology \& technology in animal } \\
\text { health } \\
\text {-Captive supplies } \\
\text {-Consolidation of feeding companies \& } \\
\text { expansion of feedyard size (2) } \\
\text { - Larger corporate feedlots } \\
\text { - Improved genetics, better feed efficiency, } \\
\text { lower costs } \\
\text {-Consolidation of feeding entities }\end{array}$ & $\begin{array}{l}\text {-Added pens and lagoon } \\
\text {-Increased capacity, } \\
\text { installed pipelines to } \\
\text { deliver runoff to irrigated } \\
\text { cropland } \\
\text { - Rapid expansion } \\
\text { - Increased capacity } \\
\text {-Added pens, added } \\
\text { lagoon, mill addition, better } \\
\text { pen maintenance } \\
\text { - Feedlots are kept cleaner } \\
\text {-Increased capacity }\end{array}$ & $\begin{array}{l}\text {-Keep improving } \\
\text {-Strict environmental } \\
\text { regulations enforced } \\
\text {-Increase capacity (2) } \\
\text {-Update, improve } \\
\text { efficiency } \\
\text {-Increased regulations, } \\
\text { especially lagoon \& } \\
\text { manure management; } \\
\text { identification of better } \\
\text { performing animals } \\
\text {-Continued expansion } \\
\text {-More small pens \& } \\
\text { flaking capacity, } \\
\text { improved use of } \\
\text { wastewater \& } \\
\text { groundwater } \\
\text {-Larger corporate } \\
\text { feedlots }\end{array}$ \\
\hline
\end{tabular}




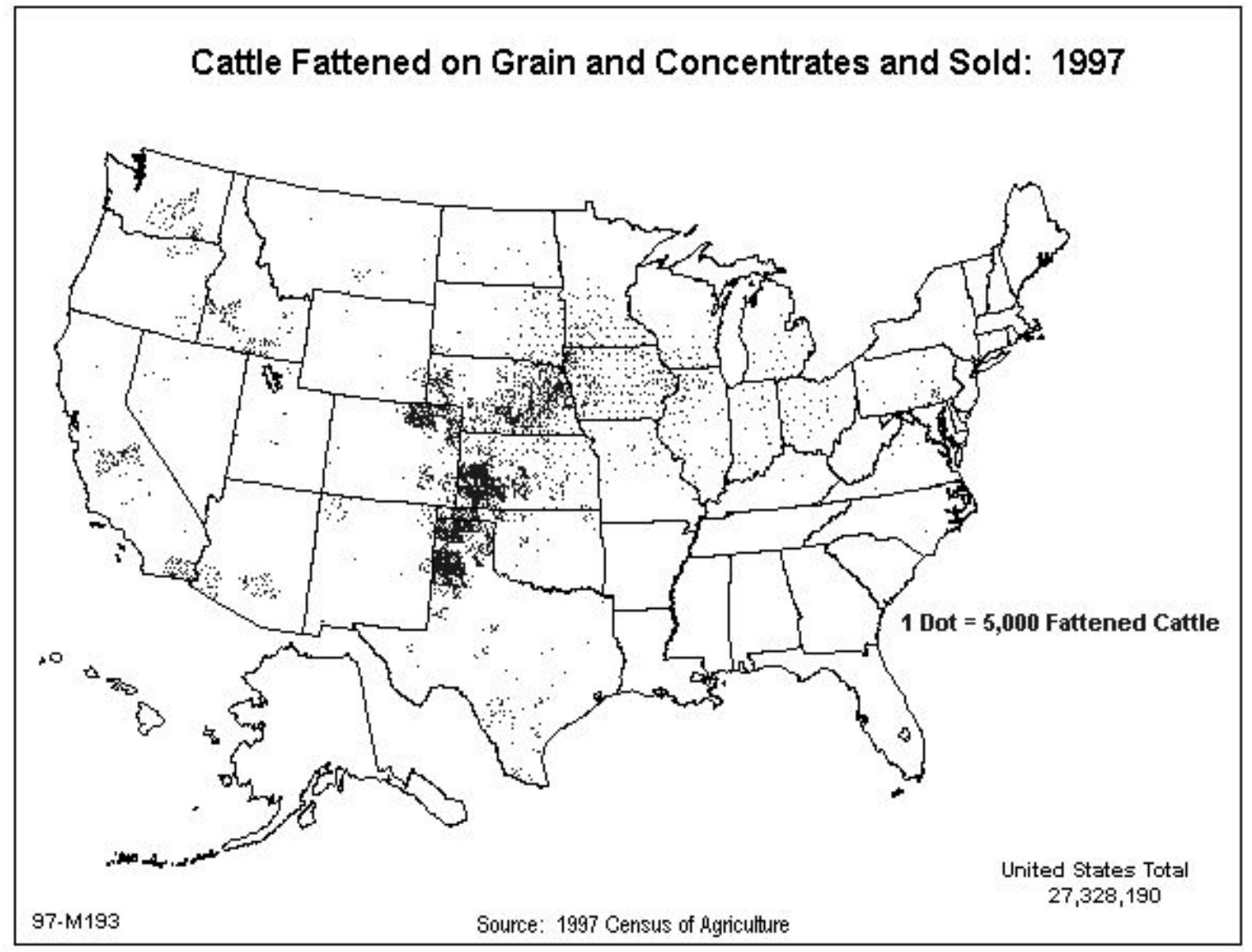

Figure 1.

Feedlot cattle sold, with major clustering in the High Plains (NASS 1997). 


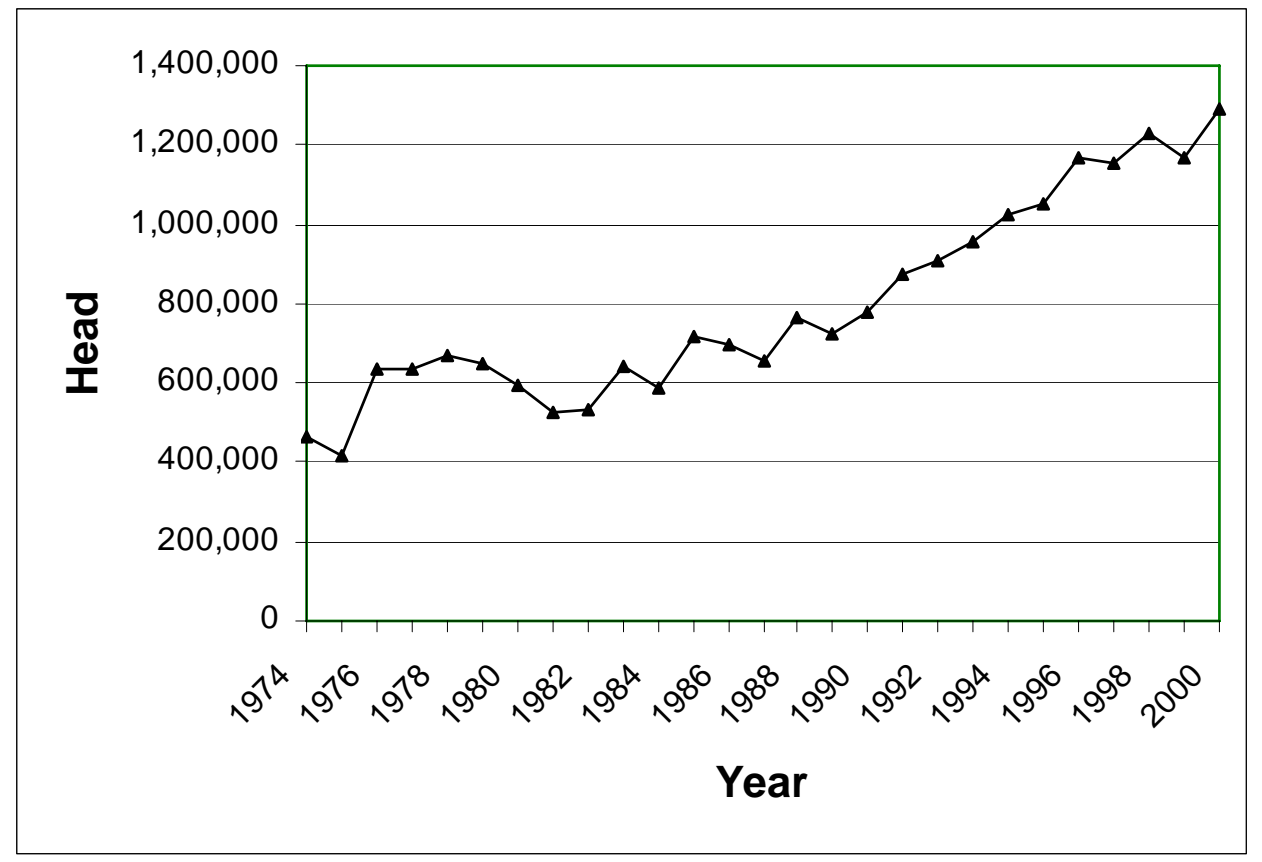

Figure 2. Cattle on feed in southwest Kansas (Clark, Finney, Ford, Grant, Gray, Hamilton, Haskell, Hodgeman, Kearny, Meade, Morton, Seward, Stanton, and Stevens counties). Source: Kansas Agricultural Statistics Service, various years. 


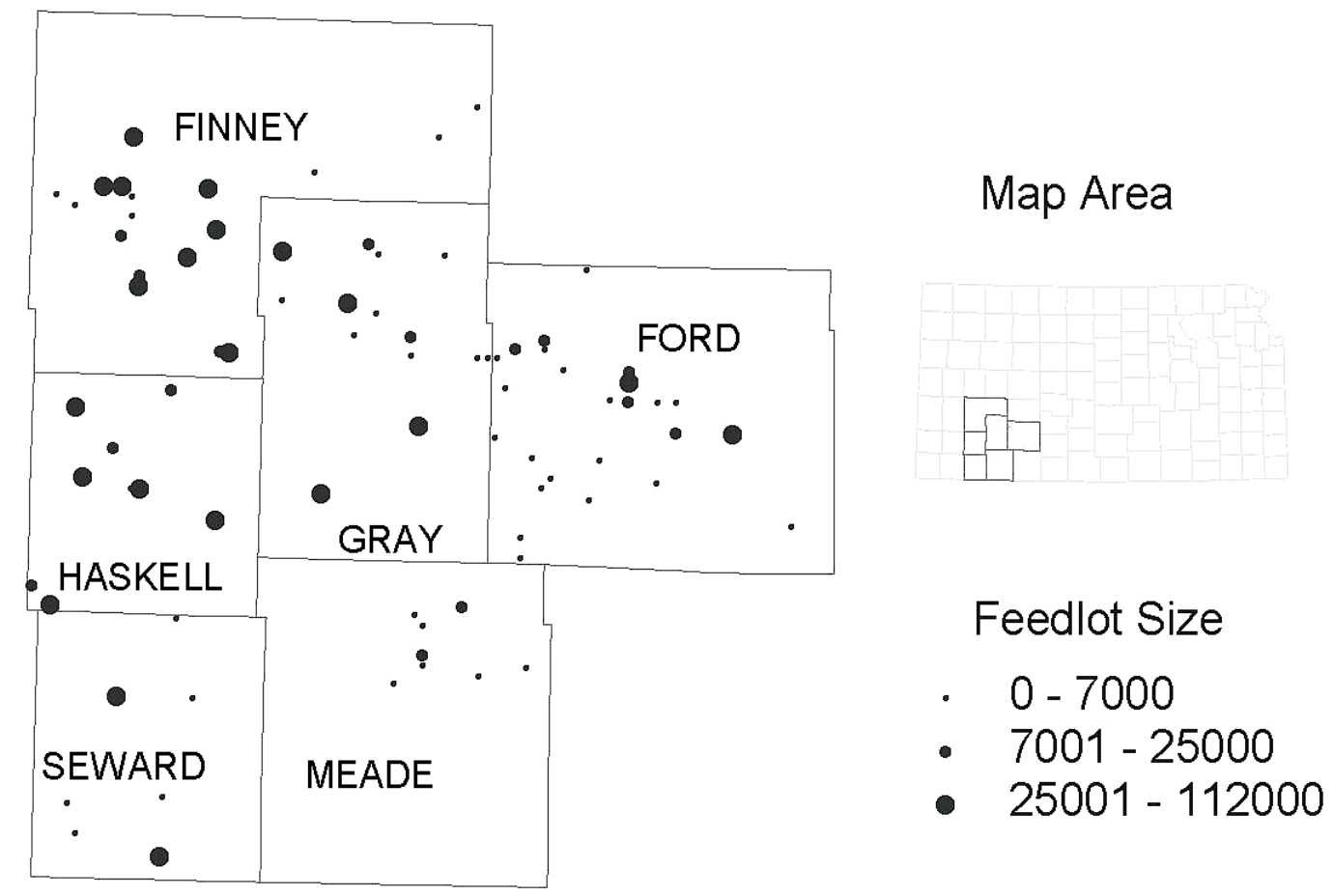

Figure 3. Study area and feedlot distribution. Source: Kansas Agricultural Statistics Service, various years. 